\title{
THE POWER OF POSITIVITY: THE ROLES OF PROSOCIAL BEHAVIOR AND SOCIAL SUPPORT TOWARD GRATITUDE
}

\author{
Taufik Akbar Rizqi Yunanto \\ Fakultas Psikologi, Universitas Surabaya, Jalan Raya Kalirungkut, Surabaya, Jawa Timur, Indonesia
}

Korespondensi:

e-mail: taufik_yunanto@staff.ubaya.ac.id

\begin{abstract}
Existing literature demonstrates that gratefulness is a critical determinant for individuals' well-being and their quality of interpersonal relationships. A sense of gratefulness provides a perspective in which individuals could have a positive evaluation in life, including the way they view challenges. Positive appreciation of life's challenges would allow individuals to increase their coping ability and would motivate them to do prosocial behavior. This study aims to determine the role of prosocial behavior and social support to individuals' sense of gratefulness. Participants in this study consisted of 250 participants aged between 13-55 years old. The instruments used in this research were Gratitude Questionnaire, Philosophies of Human Nature Altruism Scale, and Social Support Scale. Multiple regression analysis was used to analyze the data. The result revealed a strong contribution between prosocial behavior and social support toward gratitude. Gratitude and prosocial behavior contribute in enabling individuals to have a positive evaluation of life.
\end{abstract}

Article history:

Received 13 May 2019

Received in revised form 21 October 2019

Accepted 2 December 2019

Available online 29 February 2020

\section{Keywords:}

gratitude;

Indonesia;

prosocial behavior;

social support

\begin{abstract}
Abstrak - Studi terdahulu menunjukkan bahwa rasa bersyukur menjadi penentu yang penting bagi kesejahteraan individu dan kualitas hubungan interpersonal mereka. Bersyukur memberikan perspektif yang dapat membuat individu memiliki evaluasi positif mengenai hidupnya, termasuk dalam memaknai tantangan. Individu yang memandang penderitaan sebagai sesuatu yang positif dapat meningkatkan kemampuan mengatasi masalah yang baru dan termotivasi melakukan perilaku prososial. Penelitian ini bertujuan untuk mengetahui peran perilaku prososial dan dukungan sosial terhadap tingkat kebersyukuran seseorang. Partisipan dalam penelitian ini terdiri dari 250 partisipan dengan rentang usia 13-55 tahun. Instrumen yang digunakan dalam penelitian ini adalah Gratitude Questionnaire, Philosophy of Human Nature Altruism Scale, dan Social Support Scale. Analisis data dalam penelitian ini menggunakan analisis regresi berganda. Hasil analisis menunjukkan bahwa terdapat sumbangan yang positif perilaku prososial dan dukungan sosial terhadap tingkat kebersyukuran. Rasa syukur dan perilaku prososial dapat membuat seseorang memiliki evaluasi yang positif dalam kehidupannya.
\end{abstract}

Kata Kunci: dukungan sosial; Indonesia; kebersyukuran; perilaku sosial 


\section{INTRODUCTION}

Researchers agree that happiness is the ultimate goal of life for everyone, regardless whether they are in sickness or in good health (Diener \& Seligman, 2002). Diener and Seligman also suggest that a very happy person memorizes more enjoyable events in their life than they do for unfortunate events, and they show more positive emotions in life. Conversely, unhappy people will have dissatisfaction over themselves, friends, and family. Delighted people have valuable and satisfying social relationships, while unhappy people have significantly worse social relationships (Diener $\&$ Seligman, 2002). A very happy person experiences a bit of unpleasant emotion, which means that although they are often happy, the ability to feel unpleasant emotions at a particular time is still experienced.

In accordance with Diener's and Seligman's (2002) study, it indicated that although healthy people feel prosperous, they still experience dissatisfaction and negative emotions resulting from being anxious of sickness and being worried about family conditions. Thus, in order to maintain gratitude, individuals need to maintain their positive feelings and their life satisfaction (Watkins, 2013).

Being grateful will make someone have more positive outlook and a broader perspective on life, seeing that life is a gift (Peterson \& Seligman, 2004). Being grateful will cause a person to gain an emotional and interpersonal advantage. By seeing and embracing suffering as something positive, someone will be able to improve his new coping skills, both consciously and unconsciously. This skill can trigger the precipitation of self-meaning that will bring a person's life in a more positive direction (Krause, 2006). Furthermore, the study also showed that being grateful can prevent depressive and pathological conditions (Bono \& McCullough, 2006).

Gratitude comes from individual's appreciation of the positive value of his given experience (Watkins, 2013). Gratitude is one of the special forces that can be used as self-protection to reduce emotional and psychological conditions that are pathological due to important conditions (Bono \& McCullough, 2006). McCullough, Emmons, and Tsang (2004) also found that gratitude is positively related to the satisfaction of life, happiness, optimism, hope, and positive effects, and negatively related to anxiety, depression, and adverse effects. Weinstein, DeHaan, and Ryan (2010) further found that people who read and respond to vignettes of various aid events, with accidental or intentional helper motivations, indicate that the recipient experiences more gratitude for an 
unintended (voluntary) helper and predicts a positive attitude to a helper, positive effects, and feelings of attachment.

Based on the literature review above, researchers tried to see the most influential theme of gratitude in Indonesian perspective through content analysis, as recommended by Hayes (2000), on 350 respondents' answers through an open questionnaire conducted on June 17 to June 29, 2017. Preliminary study results showed that there are several themes that are considered to affect the gratitude of the people of Indonesia. The following is a preliminary study on Indonesian subjects.

Table 1.

Emerging Themes regarding How to Express Gratitude

\begin{tabular}{llcc}
\hline No & \multicolumn{1}{c}{ Themes } & Numbers & Percentage (\%) \\
\hline 1 & Religious & 203 & 57 \\
2 & Prosocial Behavior & 88 & 25 \\
3 & Meaningfulness & 23 & 6 \\
4 & Effort & 12 & 3 \\
5 & Life Satisfaction & 11 & 3 \\
6 & Unidentified & 11 & 3 \\
7 & Thankful $\quad 10$ & 3 \\
\hline \multicolumn{1}{r}{ Total } & 358 & 100 \\
\hline
\end{tabular}

Based on the preliminary study results above, the majority of participants expressed their gratitude through spiritual way. It was proven by the highest percentage shown as much as $57 \%$. This suggests that most Indonesian people express their gratitude by praying to God. When expressing gratitude to God, Indonesian people feel that there is peace despite the misery, including when one had not been able to achieve the target, when one experienced business failure, or overcomed a disaster. They believed that gratitude expressed to God could help them feel peaceful amidst the unfortunate circumstances. Common examples of how they redirected their gratitude to their spirituality includes: "Always remember Allah by saying Alhamdulillah and always carrying out the prayer", "Worship or embrace the hand [source] of gratitude", or "Praise the hamdalah, pray to God, charity". Based on those initial finding, religiosity could be assumed to affect gratitude.

Several studies have shown a positive relationship between religiosity and gratitude (Bono, Emmons, \& McCullough, 2004). Other studies have also shown that people with high levels of religiosity tend to show gratitude more often than people with low levels of religiosity (Emmons \& Kneezel, 2005). Watkins (2013) argues that gratitude is a positive affect found in religiosity. Therefore, one's religious life can direct itself to gratitude (Emmons \& McCullough, 2003). 
Human needs to interact with others. One of the things closely related to the interaction is prosocial behavior (Baron \& Branscombe, 2012). Social interaction that occurs will cause a psychological impact on the person. For example, when a person interacts constructively with others through helping behavior, he will be happy and satisfied (Burns, 2010). Prosocial behavior is the willingness of a person to voluntarily help others without the desire to get rewarded, and the person is satisfied after assisting (Baron \& Byrne, 2005). Prosocial behavior is a form of positive behavior that provides benefits for harmonious human relationships and contributes to reducing anti-social behavior (Eisenberg \& Mussen, 1989). The adoption of such prosocial behavior can indicate an atmosphere of interdependence among members of the society and the realization that in meeting the needs of life, no individual can do it alone without the help of others.

In order for everyone to survive, they need mutual support as a reflection of the attitude of cooperation and support in society. This behavior can be in the form of willingness to help, share, and contribute (Bartal, Decety, \& Mason, 2011). Prosocial behavior develops from early childhood through later in life. The development of this behavior has improved as people ages (Eisenberg \& Mussen, 1989). It is assumed that as individuals age, their social maturity and social responsibility grow. Prosocial behavior during the youth is a predictor of behavior as adults. Pulkkinen, Nygren, and Kokko (2002) reported that a person who at a young age has high prosocial behavior has less likelihood to commit crimes that led to imprisonment.

Considering the positive contribution of prosocial behavior to individuals, especially in preventing the occurrence of social conflict, prosocial behavior needs to be built and maintained. If prosocial behavior is not preserved, social conflict is likely to occur. The existence of social conflicts left unchecked, or without the control of the community, that will result in the emergence of behaviors that tend to be harmful and contrary to the norm or against the rules, laws, ethics, values, and morals prevailing in society. It can lead to fights, crime, theft, drug abuse, extramarital sex, and rape (Sunarwiyati, 1985). The attitude of mutual respect and respect for each other is a noble value that is highly respected and very important to be maintained or even enhanced in Indonesian society nowadays.

Indonesian people have applied the noble value as a reflection of the value of harmony in the life of society. The manifestation of the noble values is the prosocial behavior that reflects mutual helping, cooperating, sharing, donating, and altruistic behavior (Janssens \& Deković, 1997), in the form of mutual cooperation among members of the community. Without the noble values and prosocial behavior, Indonesian society could potentially be quickly divided. 
Gratitude shows the essence of positive behavior that becomes an indicator of orientation, meaning, and appreciation of the positivity in life. Individuals who feel more grateful have a more positive view of the social environment, engage more in employing productive coping strategies, and have better sleep quality, positive environmental focus, and high appreciation of lives, such as decreased negative aspects of self, life, and future (Wood, Joseph, \& Maltby, 2008). Gratitude can be achieved by considering its contributing factors. Internal factors that affects gratitude, include: attractiveness and intelligence (Passer \& Smith, 2009), a person's worldview (Compton \& Hoffman, 2012), self-acceptance (Bergsma \& Ardelt, 2012), age and religion (Seligman, 2002), while the external factors are money or wealth, marriage, and social life (Seligman, 2002).

In relation to social life, one thing that affects gratitude is social support. Studies show that gratitude cannot only be deliberately cultivated but can increase the level of both creatures and happiness among those who cultivate it. In addition, gratitude are mainly expressed to others who are associated with increased energy levels, optimism, and empathy (Burns, 2010).

Social support is one form of source of support that comes from others (Berns, 2017). Such a support can have both positive and negative effects on the mental health and well-being of individuals (Cohen \& Syme, 1985). In addition, social support is a protective factor that can assist individuals when faced with pressing life's experience (Passer \& Smith, 2009). Tahmasbipour and Taheri (2012) suggest that social support is positively associated with mental health, especially gratitude.

With the exposure of the image of gratitude, prosocial behavior, and social support in Indonesia, it becomes an underlying factor for the current study to examine the gratitude of Indonesians. The above literature raises an assumption of whether prosocial behavior and social support have a significant role in the gratitude of Indonesians, which serves as the study aim. In particular, the study aims to empirically investigate the role of prosocial behavior and social support to gratitude among Indonesian people. We hypothesized that there is a positive relationship between prosocial behavior and social support with gratitude.

\section{METHOD}

\section{Partisipants}

Participants in the study were 250 Indonesian people from adolescent to adult with age range 13 to 55 years old $(N$ male $=67 ; N$ female $=183)$, obtained through online survey. This study 
is part of the large study that investigates gratitude in Indonesian people. Informed consent was obtained from all participants via email. Upon their consent being electronically verified, participants were sent a link to complete the online questionnaire.

\section{Instruments}

Three scales were used in this study: Gratitude Questionnaire-6 (GQ-6), Social Support Scale, and Philosophies of Human Nature Altruism Scale.

Gratitude Questionnaire 6 (GQ 6). The scale of gratitude is adapted from McCullough, Emmons, and Tsang (2004), consists of 6 items. The original scale development obtained the value of Cronbach's alpha of .786.

Social Support Scale. Peer social support is a source of help provided by peers or adolescents of the same age or maturity in order to improve well-being. Peer social support consists of emotional support, appreciation support, instrumental support, and informative support. This variable was measured using a peer-social support scale developed by Selistiowati (2010), consists of 34 items. Scores earned by the subject indicated the level of peer social support. The higher the score obtained, then peer social support is also high. Conversely, a low score indicates low peers' social support of the subject. The original scale development obtained the value of Cronbach's alpha of 944 .

Philosophies of Human Nature Altruism Scale. This scale was developed from the aspects of prosocial behavior proposed by Wrightsman (1964). The basic dimensions of Philosophies of Human Nature Altruism Scale are: 1). Trustworthiness; 2). Altruism; 3). Independence; 4). Strength of Will and Rationality; 5). The Complexity of Human Nature; and 6). The Variability in Human Nature. The scale consists of 14 items and was proven to have good internal reliability $(\alpha=.733)$ in our initial study using 94 participants.

\section{Analysis Techniques}

Data was analysed using multiple linear regression analysis from IBM SPSS 23 to investigate the contribution of $\mathrm{x}$ and $\mathrm{y}$ to $\mathrm{z}$. 


\section{ANALYSIS AND RESULTS}

The result suggests a significant contribution of $\mathrm{X}$ and $\mathrm{Y}$ to $\mathrm{Z}\left(R^{2}=.565, F=66,628, p=\right.$ $.001)$. Thus, prosocial behavior and social support explains $56.5 \%$ of the gratitude scores variability.

In addition to multiple regression analysis, the researcher also tested the regression coefficients using $F$ Test to determine whether the independent variables significantly influence the dependent variable. The result confirms that emotion regulation and social support simultaneously contribute to participants' scores of gratitude.

Table 2.

Summary of Hierarchical Regression Analysis for Variables Predicting Gratitude $(N=250)$

\begin{tabular}{lrrr}
\hline & \multicolumn{3}{c}{ Model } \\
\cline { 2 - 4 } \multicolumn{1}{c}{ Variable } & $\boldsymbol{B}$ & $\boldsymbol{S} \boldsymbol{E} \boldsymbol{B}$ & $\boldsymbol{\beta}$ \\
\hline Prosocial Behavior & 1.226 & .207 & $.524^{* *}$ \\
Social Support & .246 & .073 & $.299^{* *}$ \\
$R^{2}$ & & .565 & \\
$F$ & & 66.628 & \\
\hline Note: ${ }^{* *}=$ significant at .001 level & &
\end{tabular}

\section{DISCUSSION}

The finding suggests that prosocial behavior and social support positively contribute to individuals' gratitude. The result concurs with what McCullough, Emmons, and Tsang (2004) have suggested that factors affecting gratitude are prosocial behavior and social support.

Gratitude in Indonesia (especially in Javanese, as being Indonesia's largest ethnicity) cannot be separated from the culture of collectivism and religiosity (Sutrisno \& Putranto, 2005). This is because the majority of Indonesian people consider that religion is an important thing (Pew Research, 2008). Religion and belief system play an important role for Indonesian society, and are part of individual's personal identity (Colbran, 2010). 
Indonesians also consider it essential to build social relationships. Thus, peer supports have an important and central role in providing accessible forms of general support. McGrath, Brennan, Dolan, and Barnett (2009) confirm that friends are an essential source of support that provides emotional support. Emotional support usually involves a close relationship, manifested in providing reliable, accessible, and unconditional support whenever needed.

The study found that prosocial behavior contributes to gratitude. This is supported by Emmons and McCullough (2003) study that gratitude has a positive impact on interpersonal quality, while performing prosocial behaviors such as helping sick people will have an impact on increasing the ability to express affection and attention to others, and increase appreciation from others to prosocial actors for acting in accordance with social norms and agreements (Stukas, Snyder, \& Clary, 2016).

Performing prosocial behavior can also benefit individuals in gaining appreciation, status, and lessons from their experience helping others (Bandura, 2012). Someone who assists others in overcoming their challenges will as well gain a lesson for their future reference when overcoming a similar situation. Such an experience will shape individuals to become resilient when dealing with similar life challenges. Such an experience would, in turn, make someone more grateful in life (Stukas, Snyder, \& Clary, 2016).

When someone can help others, it will have a very positive impact on both the helper and the one who receives help. Gratitude enables individuals to embrace in the positive emotions and to reconcile one's heart. Engagement with positive emotions would be a significant factor in supporting individuals to exercise their adaptive ability. This is because grateful individuals tend to genuinely accept their life (Vailant, 2000).

The results show that social support and prosocial behavior simultaneously contribute to individual's level of gratitude. This could plausibly be understood as someone who can help others feels more grateful and calm than people who do not have the opportunity to help (Williamson \& Clark, 1992). Positive evaluation gained after doing prosocial behavior is believed to increase gratitude. Emmons (2007) also found that someone who perceives their life as a blessing or gift, and consciously learns to behave gratefully, will experience higher level of well-being.

Limitations in this study includes wide age ranges of participants, which hinders the findings to be discussed within developmental perspective. The study also did not consider individuals' ethnicity and cultural values, which might as well play a determining part in an individual's perspective on gratitude. The scales used in the current study also might not be the best 
instruments in measuring the studied variables as it does not consider possibility of participants' providing socially desirable responses.

\section{CONCLUSION AND RECOMMENDATION}

\section{Conclusion}

The result shows that social support and prosocial behavior are important determinants to individual's gratitude. Having a sense of gratitude enables individuals to overcome various life circumstances.

\section{Theoretical Recommendation}

Future studies could benefit from exploring the variables by controlling possibility for participants providing socially desirable responses or by using other methods or tools for data collections. Considering that gratitude tends to be age-specific, future studies could also further specify the exploration on certain age ranges to enable age-related interpretation. While the present study provides preliminary finding regarding the contribution of prosocial behavior and social support to an individual's sense of gratitude, future studies might emphasize contextual factors and cultural meanings in exploring such phenomena.

\section{Practical Recommendation}

Practically termed, the study suggests that having a reliable social support and a positive intention on performing prosocial behavior is a good strategy to increase an individual's level of gratitude, which might act as a coping resource in overcoming challenges in life.

\section{REFERENCES}

Bandura, A. (2012). On the functional properties of perceived self-efficacy revisited. Journal of Management, 38(1), 9-44.

Baron, R. A., \& Branscombe, N. R. (2012). Social psychology (13rd ed.). New York, NY: Pearson.

Baron, R. A., \& Byrne, D. (2005). Psikologi sosial. Jakarta: Penerbit Erlangga. 
Bartal, I. B. A., Decety, J., \& Mason, P. (2011). Empathy and pro-social behavior in rats. Science, 334(6061), 1427-1430.

Bergsma, A., \& Ardelt, M. (2012). Self-reported wisdom and happiness: An empirical investigation. Journal of Happiness Studies, 13(3), 481-499.

Berns, N. S. (2017). Framing the victim: Domestic violence, media, and social problems. New York, NY: Routledge.

Bono, G., Emmons, R. A., \& Mccullough, M. E. (2012). Gratitude in practice and the practice of gratitude. Positive Psychology in Practice, 29, 464-481. doi:10.1002/9780470939338.ch29.

Bono, G., \& McCullough, M. E. (2006). Positive responses to benefit and harm: Bringing forgiveness and gratitude into cognitive psychotherapy. Journal of cognitive Psychotherapy, 20(2), 147.

Burns, G. W. (Ed.). (2010). Happiness, healing, enhancement: Your casebook collection for using positive psychotherapy. Hoboken: Wiley.

Cohen, S. E., \& Syme, S. L. (1985). Social support and health. New York, NY: Academic Press.

Colbran, N. (2010). Realities and challenges in realising freedom of religion or belief in Indonesia. The International Journal of Human Rights, 14(5), 678-704.

Compton, W. C., \& Hoffman, E. (2012). Positive psychology: The science of happiness and flourishing (2nd ed.). Belmont, CA: Wadsworth.

Diener, E., \& Seligman, M. E. P. (2002). Very happy people. Psychological Science, 13(1), 81-84. doi: $10.1111 / 1467-9280.00415$

Eisenberg, N., \& Mussen, P. H. (1989). The roots of prosocial behavior in children. Cambridge: Cambridge University Press.

Emmons, R. A. (2007). Thanks: How the new science of gratitude can make you happier. New York, NY: Houghton Mifflin Company.

Emmons, R. A., \& Kneezel, T. T. (2005). Giving thanks: Spiritual and religious. Journal of Psychology and Christianity, 24(2), 140-148.

Emmons, R. A., \& McCullough, M. E. (2003). Counting blessings versus burdens: An experimental investigation of gratitude and subjective well-being in daily life. Journal of Personality and Social Psychology, 84, 377-389.

Hayes, N. (2000). Doing psychological research. Philadelphia, PA: Taylor \& Francis Group.

Janssens, J. M., \& Deković, M. (1997). Child rearing, prosocial moral reasoning, and prosocial behaviour. International Journal of Behavioral Development, 20(3), 509-527. 
Krause, N. (2006). Gratitude toward God, stress, and health in late life. Research on Aging, 28(2), 163-183.

McCullough, M. E., Emmons, R. A., \& Tsang, J. A. (2004). The grateful disposition: A conceptual and empirical topography. Journal of Personality and Social Psychology, 82, 112-127. doi:10.1037/0022-3514.82.1.112

McGrath, B., Brennan, M. A., Dolan, P., \& Barnett, R. (2009). Adolescent well-being and supporting contexts: A comparison of adolescents in Ireland and Florida. Journal of Community \& Applied Social Psychology, 19(4), 299-320.

Passer, M. W., \& Smith, R. E. (2009). Development over the life span. In Psychology: The science of mind and behavior. Boston: McGraw-Hill.

Peterson, C., \& Seligman, M. E. (2004). Character strengths and virtues: A handbook and classification (Vol. 1). New York, NY: Oxford University Press.

Pew Research. (2008). Unfavourable views of Jews and Muslims in the increase in Europe. Retrieved from http://www.pewglobal.org/2008/09/17/chapter-2-religiousness/.

Pulkkinen, L., Nygren, H., \& Kokko, K. (2002). Successful development: Childhood antecedents of adaptive psychosocial functioning in adulthood. Journal of Adult Development, 9(4), 251265.

Seligman, M. E. (2002). Positive psychology, positive prevention, and positive therapy. Handbook of Positive Psychology, 2(2002), 3-12.

Selistiowati, A. (2010). Hubungan persepsi siswa terhadap guru dan dukungan sosial teman sebaya dengan motivasi belajar matematika (Unpublished thesis). Universitas Gadjah Mada, Indonesia.

Stukas, A. A., Snyder, M., \& Clary, E. G. (2016). Understanding and encouraging volunteerism and community involvement. The Journal of Social Psychology, 156, 243-255. doi:10.1080/00224545.2016.1153328

Sunarwiyati, S. (1985). Pengukuran sikap masyarakat terhadap kenakalan remaja di DKI Jakarta (Laporan penelitian). Universitas Indonesia, Indonesia.

Sutrisno, M., \& Putranto, H. (2005). Teori-teori kebudayaan. Yogyakarta: Kanisius.

Tahmasbipour, N., \& Taheri, A. (2012). A survey on the relation between social support and mental health in students Shahid Rajaee University. Procedia-Social and Behavioral Sciences, 47, 5-9.

Vailant, G. (2000). The mature defenses: Antecedents of joy. American Psychologist, 55, 89-98. 
Watkins, P. C. (2013). Gratitude and the good life: Toward a psychology of appreciation. Dordrecht: Springer Science \& Business Media.

Weinstein, N., DeHaan, C. R., \& Ryan, R. M. (2010). Attributing autonomous versus introjected motivation to helpers and the recipient experience: Effects on gratitude, attitudes, and wellbeing. Motivation and Emotion, 34(4), 418-431.

Williamson, G. M., \& Clark, M. S. (1992). Impact of desired relationship type on affective reactions to choosing and being required to help. Personality and Social Psychology Bulletin, 18(1), 10-18.

Wood, A. M., Joseph, S., \& Maltby, J. (2008). Gratitude uniquely predicts satisfaction with life: Incremental validity above the domains and facets of the five factor model. Journal of Personality and Individual Differences, 45, 49-54.

Wrightsman Jr, L. S. (1964). Measurement of philosophies of human nature. Psychological Reports, 14(3), 743-751. 